\title{
Immunoturbidimetric assay for estimating free light chains of immunoglobulins in urine and serum
}

\author{
C R Tillyer, J Iqbal, J Raymond, M Gore, T J McIlwain
}

\begin{abstract}
An immunoturbidimetric assay for the assessment of free $\kappa$ and $\lambda$ light chains of immunoglobulins was developed using a commercial polyclonal antiserum with reactivity towards epitopes on the light chains, which are not expressed when they are bound to heavy chains. The assay, on a centrifugal analyser, is simple and rapid. The limit of detection is $5 \mathrm{mg} / \mathrm{l}$ of free light chain, with an assay range of $5-120 \mathrm{mg} / 1$, intrabatch precisions from $1 \cdot 5-6 \cdot 4 \%$, and interbatch precisions from $6 \cdot 5-8 \cdot 9 \%$. The assay was only slightly less sensitive than colloidal gold staining of cellulose acetate electrophoreses for the detection of BenceJones protein in urine. For the serial monitoring of response to chemotherapy in patients with myeloma, the assay correlated well with serum paraprotein estimates obtained by densitometric scanning of Ponceau stained cellulose acetate electrophoreses, but not with serum $\beta-2$ microglobulin measurements, even after correction for the effects of creatinine.
\end{abstract}

These assays may prove to be of use for the monitoring of tumour response in the treatment of Bence-Jones myeloma.

The monoclonal immunoglobulins secreted in myeloma have many of the properties required of the ideal tumour marker and the value of quantifying the concentration of paraprotein in serum as a guide to the detection, treatment, and monitoring of this condition is undisputed. ${ }^{1}$ About $10-20 \%$ of myelomas, however, secrete only the free light chains of immunoglobulins, historically known as Bence-Jones protein, ${ }^{2}$ and until recently there has been relatively little effort routinely to quantitate these paraproteins in urine as an aid to disease monitoring and treatment. There are several possible reasons for this. The method used for quantifying serum paraproteins (densitometric scanning of stained cellulose acetate or agarose electrophoreses) has not been routinely applied to detection of urinary Bence-Jones protein. This has probably been due to the requirement to concentrate urines because of the insensitivity of the protein stains used, which renders the estimation far more laborious. A further problem is the highly variable protein composition of urine, particularly in patients with myeloma. This can lead to inaccuracies in the scan, due to the different dye binding properties of the different proteins, and also in the reference protein assay used to calibrate the scan. The accuracy and imprecision of this assay is also very dependent on the degree of homology and invariability of the proteins in the sample and standard.

Immunochemical assays have been developed, ${ }^{3}$ but as the antisera were raised to bound light chains any immunoglobulin in the assay had to be removed by gel or membrane filtration techniques which were not suitable for routine analysis. ${ }^{45}$ Antisera to epitopes which are only expressed by the free light chain and not on bound light chains will overcome this problem, but the development of free light chains assays has been hindered because antisera with sufficient specificity and avidity have been commercially available only recently, even though they were first reported 25 years ago. ${ }^{6}$ Immunochemical assays also have a protein calibration problem due to the differential reactivity of antisera to standards containing a heterogenous collection of proteins and samples containing a homogenous or different heterogenous set of proteins. Furthermore, different antisera can react in a completely different manner to the same standard or sample. In practice, however, immunochemical assays are reliably consistent for monitoring paraproteins in patients when the same batch of antiserum is used. ${ }^{7}$

In the past eight years several free light chain assays have appeared using radioimmunoassay $^{8}$ and enzyme immunoassay techniques $^{9-11}$ with commercial polyclonal or monoclonal) antisera, which have been used to monitor treatment in patients with BenceJones proteinuria and myeloma. We used commercially available polyclonal anti-free light chain antisera to develop a simple, direct, and rapid immunoturbidimetric assays on a centrifugal analyser for free $\kappa$ and $\lambda$ light chains in serum and urine.

\section{Methods}

FREE LIGHT CHAIN ASSAYS

Reagents: sodium phosphate buffer pH 7.0 (0.067 mol/l). Polyethylene glycol (PEG) 6000 (BDH, Poole, Dorset, England) $6 \%(\mathrm{w} / \mathrm{v})$ in phosphate buffer (6\% PEG). 
Antiserum: rabbit anti-human free $\kappa$ (A100:Lot 088) and anti-human free $\lambda$ (A101:Lot 079) light chains (Dako Ltd, High Wycombe, Buckinghamshire, England).

Preparation of light chain standards: urine samples from patients with Bence-Jones protein myeloma were pooled, precipitated with $70 \%$ ammonium sulphate, dialysed against phosphate buffered saline (PBS), pH $7 \cdot 0$, and light chain fractions obtained after passage over an Ultrogel AcA 54 column equilibrated with PBS; fractions were pooled and adjusted to a final concentration of $0.5 \mathrm{~g} / 1$. Purity was more than $99 \%$ as assessed by polyacrylamide and cellulose acetate electrophoresis. Working standards were prepared from this solution by dilution in $6 \%$ PEG.

Assay procedure: standards and samples were assayed on a Cobas Bio centrifugal analyser (Roche, Welwyn Garden City, Hertfordshire) using a 1 in 20 dilution of antiserum in $6 \%$ PEG. The Cobas Bio variable listing was as follows: (1) units $\mathrm{mg} / \mathrm{l}$; (2) calculation factor 1000 ; (3) standard 1 concentration 0 ; (4) standard 2 concentration 0 ; (5) standard 3 concentration 0 ; (6) limit 0 ; (7) temperature ${ }^{\circ} \mathrm{C} 25$; (8) type of analysis 5; (9) wavelength (nm) 340 ; (10) sample volume $(\mu \mathrm{l}) 20$; (11) diluent volume $(\mu \mathrm{l}) 45$; (12) reagent volume $(\mu \mathrm{l}) 250$; (13) incubation time (seconds) 0 ; (14) start reagent volume $(\mu \mathrm{l}) 0$; $(15)$ time of first reading (seconds) 0.5 ; (16) time interval (seconds) 30 ; (17) number of readings 30 ; (18) blanking mode 1 ; (19) printout mode 1.

CELLULOSE ACETATE ELECTROPHORESIS AND PARAPROTEIN QUANTITATION

The method of Kohn, ${ }^{12}$ with the addition of Tween-20 in the wetting buffer, was used. Strips were stained with Ponceau $S$ for densitometric scanning, and with nigrosine and colloidal gold stain ${ }^{13}$ for detection of urinary Bence-Jones protein. Immunofixation was carried out using a modification of the method of Kohn and Riches. ${ }^{14}$

$\beta-2$ microglobulin assay: the immunoturbidimetric assay of Tillyer and Rawal was used. ${ }^{15}$ Calibration standards were from the Protein Reference Unit, Sheffield, England. The working range of this assay was $0.5-$ $16 \mathrm{mg} / \mathrm{l}$, with samples going into antigen excess above $30 \mathrm{mg} / \mathrm{l}$.

Serum and urine immunoglobulins: These were assayed in serum and urine using goat antihuman IgA, IgG, and IgM (Guildhay, Surrey, England) in an immunoturbidimetric assay after the method of Deverill (personal communication), using $6 \%$ PEG reaction buffer and SPS-01 calibration standard (Protein Reference Unit, Sheffield).

Calibration curves were fitted using a third order polynomial least-squares algorithm. Imprecisions were estimated using an ANOVA technique for duplicate control samples in each batch. Parallelism was assessed by the regression of the diluted sample on the standard. Spearman's rank correlation $(\rho)$ was used to assess the correlation between estimation of serum paraprotein, urinary free light chains, and $\beta-2$ microglobulin concentration.

\section{CLINICAL EVALUATION}

A random sample of 12 patients attending the myeloma unit at the Royal Marsden hospital, all with Bence-Jones protein in the urine, determined by cellulose acetate electrophoresis, were monitored for about 100 days for serum paraprotein concentrations, $\beta-2$ microglobulin and immunoglobulins; and urine total protein, immunoglobulins, and free light chains. The paraprotein types were $\mathrm{G} \kappa, \mathrm{BJ} \kappa(\mathrm{n}=3) ; \quad \mathrm{G} \lambda, \mathrm{BJ} \lambda(\mathrm{n}=4) ; \mathrm{A} \kappa, \mathrm{BJ} \kappa$ $(\mathrm{n}=1) ; \mathrm{A} \lambda, \mathrm{BJ} \lambda(\mathrm{n}=1) ; \mathrm{D} \kappa, \mathrm{BJ} \kappa(\mathrm{n}=1) ;$ and $B J \kappa(n=2)$. Nine of the patients underwent various combinations of high dose chemotherapy (including cyclophosphamide/ vincristine, adriamycin, methylprednisolone/ melphalan/busulphan, with or without bone marrow autograft).

\section{Results}

FREE LIGHT CHAIN ASSAYS

Calibration curve: calibration curves for both $\kappa$ and $\lambda$ light chain assays were non-linear over the chosen concentration range (5-120 mg/l), but showed a high degree of reproducibility over the range for each batch of antiserum (figs 1 and 2).

Recovery: recovery of light chain using spiked urines was $90-103 \%$ (mean $96 \%$ ) for the $\kappa$ assay and $95-101 \%$ (mean $99 \%$ ) for the $\lambda$ assay. Detection limit: the detection limit (three times the standard deviation of the blank response from zero) was $5 \mathrm{mg} / \mathrm{l}$ for both assays.

Cross reactivity: using free light chain standards the cross reactivity of free $\kappa$ light chains with anti-free $\lambda$ antiserum and free $\lambda$ light chains with anti-free $\kappa$ antiserum were both less than $3.2 \%$, using the free light chains standard. The true cross reactivity between light chains is less than this according to others using antiserum from the same source ${ }^{89}$; the sensitivity of our assay was limiting in this respect. The cross reactivities of the free light chain antisera to sera of patients with myeloma containing no free light chains (as determined by electrophoresis) are shown in table 1 . As expected the degree of cross reactivity varied considerably among the patients, the maximum being $2 \cdot 2 \%$. This is much higher than others have shown using polyclonal IgG, ${ }^{89}$ but is not sufficient to cause any major problems in the urine free light chain assay.

Imprecision: imprecision estimates for pooled urines are shown in table 2 . These are comparable with immunoturbidimetric assays for other proteins.

Parallelism: data are presented in table 3 . Although sample and standard response curves were apparently parallel, regression analysis of the observed and expected concentrations showed evidence for non-parallelism in one out of three $\lambda$ urines and one of the $\kappa$ urines. Again, this may be expected in the assay of monoclonal free light chains. The deviations from parallelism were not very high, however, and we did 


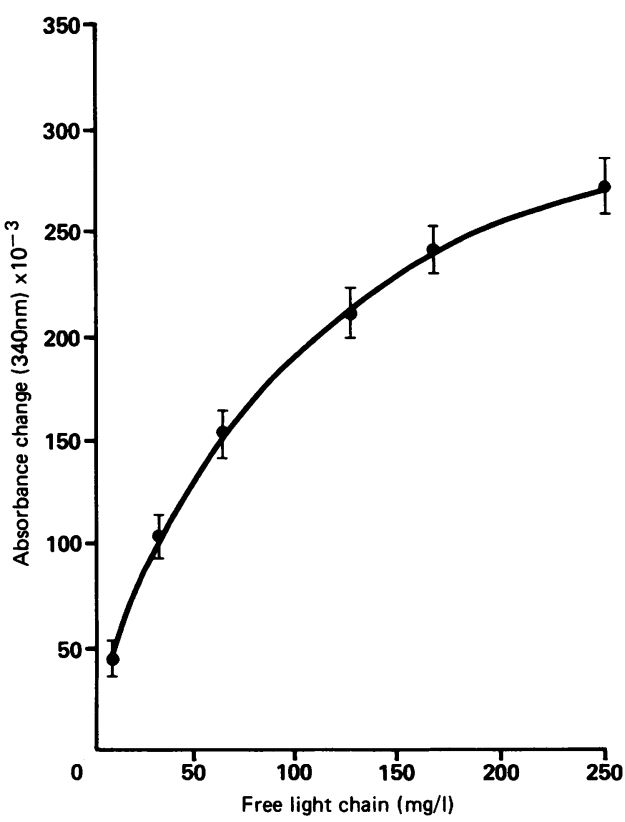

Figure 1 Calibration curves for $\kappa$ free light chain assays. Points show mean SD for nine different assay calibration curves using the same batch of antiserum.

not consider that they would seriously affect the accuracy of the assay.

\section{CLINICAL STUDIES}

Reference ranges: the detection limit of the assay was not low enough to determine a true normal range. The working detection limit of the assay was $8 \mathrm{mg} / \mathrm{l}$, the concentration of the lowest

Table 1 Cross reactivity of free light chain antisera to bound light chains

\begin{tabular}{|c|c|c|}
\hline \multirow{2}{*}{$\begin{array}{l}\text { Paraprotein } \\
\text { (no of samples) }\end{array}$} & \multicolumn{2}{|c|}{ Cross reactivity (\%) } \\
\hline & Anti-א & Anti- $\lambda$ \\
\hline $\begin{array}{l}\mathrm{G} \kappa(8) \\
\mathrm{G} \lambda(1) \\
\mathrm{A} \kappa(1) \\
\mathrm{A} \lambda(2) \\
\mathrm{M} \kappa(2) \\
\mathrm{M} \lambda(2)\end{array}$ & $\begin{aligned} &< 0.24-1.96 \\
&< 0.8 \\
& 1.6 \\
&<0.06,<0.45<0.37,2.1 \\
&<0.06,1.25\end{aligned}$ & $\begin{array}{c}<0.04-<0.4 \\
0.16 \\
<1 \\
0.02,<0.45 \\
<0.37,2.24 \\
0.023,0.35\end{array}$ \\
\hline
\end{tabular}

Table 2 Imprecision estimates for light chain assays

\begin{tabular}{|c|c|c|c|c|c|c|c|}
\hline \multicolumn{4}{|l|}{$\kappa$} & \multicolumn{4}{|l|}{$\lambda$} \\
\hline$m g / l$ & $C V_{\text {w }}$ & $C V_{b}$ & $n$ & $m g / L$ & $C V_{w}$ & $C V_{b}$ & $n$ \\
\hline $\begin{array}{r}12.7 \\
95.6 \\
187.6\end{array}$ & $\begin{array}{l}2 \cdot 1 \\
2 \cdot 6 \\
6 \cdot 4\end{array}$ & $\frac{\bar{Z}}{8 \cdot 9}$ & $\begin{array}{r}10 \\
10 \\
8\end{array}$ & $\begin{array}{r}14 \cdot 1 \\
72 \cdot 3 \\
177 \cdot 3\end{array}$ & $\begin{array}{l}2.7 \\
1.5 \\
4.6\end{array}$ & $\frac{-}{6.5}$ & $\begin{array}{l}10 \\
10 \\
10\end{array}$ \\
\hline
\end{tabular}

$\mathrm{CV}_{\mathrm{w}}=$ intrabatch $\mathrm{CV}(\%)$.

$\mathrm{CV}_{\mathrm{b}}=$ interbatch $\mathrm{CV}(\%)$.

Table 3 Parallelism of samples and standards

\begin{tabular}{lcc}
\hline \multicolumn{3}{l}{ Regression of observed sample concentration on expected } \\
\hline Sample & Slope $(95 \%$ CI $)$ & Intercept $(95 \%$ CI $)$ \\
\hline$\lambda$ & $0.98(0.94-1.03)$ & $-1.30(-2.99-0.39)$ \\
$\lambda$ & $1.03(0.83-1.23)$ & $7.86(-8.40-24.1)$ \\
$\lambda$ & $0.93(0.90-0.96)^{\star}$ & $2.97(-1.50-7.4)$ \\
$\kappa$ & $0.88(0.76-0.98)^{\star}$ & $-8.70(-23.50-6.13)$ \\
$\kappa$ & $1.01(0.93-1.10)$ & $4.45(-0.39-9.31)$ \\
\hline \multirow{2}{*}{ Confidence interval (CI) for } & slope does not encompass \\
expected value of unity.
\end{tabular}

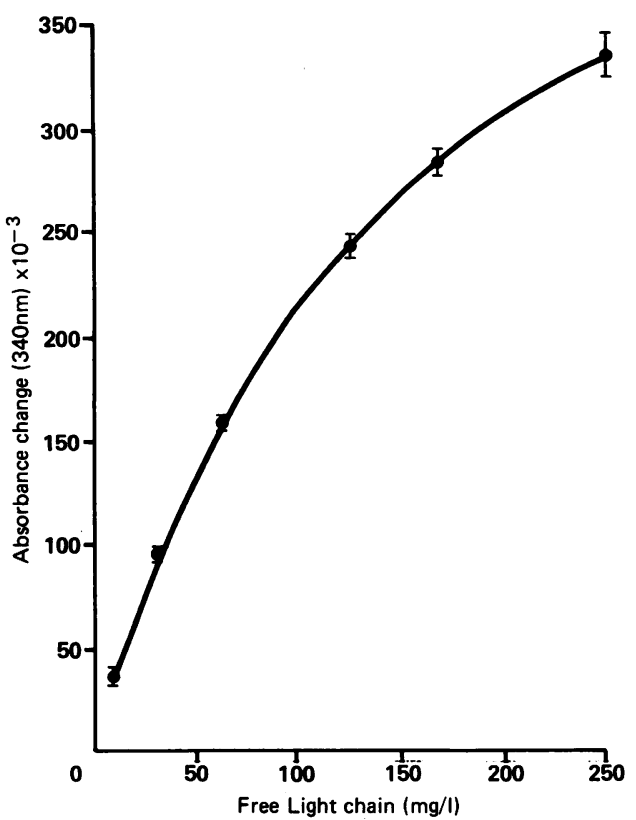

Figure 2 Calibration curves for $\lambda$ free light chain assays. Points show mean SD for seven different assay calibration curves using the same batch of antiserum.

standard, which is very close to the upper limit of the normal range for absolute concentration of free light chains as determined by other authors $\left(8 \mathrm{mg} / 1\right.$ for $\kappa^{910}$, and $2 \cdot 1 \mathrm{mg} / 1$ for $\left.\lambda^{9}\right)$. In a sample of seven 24 hour urine collections from normal hospital staff absolute concentrations of free $\kappa$ and $\lambda$ chains were all less than $8 \mathrm{mg} / \mathrm{l}$. During chemotherapy, most of the patients showed extremely high variation in glomerular filtration rates due to factors such as the toxic effects of chemotherapy, administration of intravenous fluids, diuretics and varying fluid intake. Results were therefore corrected for the effects of creatinine to permit a meaningful comparison of spot urine samples.

Patient monitoring: the nine treated patients had initial urine free light chain concentrations ranging from 615 to $3 \mathrm{mg} / \mathrm{mmol}$ creatinine; five of these responded biochemically by dropping their urinary free light chains to undetectable concentrations in at least one sample during treatment. Two typical cases are shown in figs $3 \mathrm{~A}$ and $\mathrm{B}$. The patient in fig $3 \mathrm{~B}$ showed a transient rise in $\beta-2$ microglobulin in conjunction with the development of a transient paraprotein $(\mathrm{G} \kappa)$ in the serum. This seemed to be part of the general bone marrow response observed after high dose chemotherapy as the patient achieved clinical remission soon after. Two cases showed a partial response to chemotherapy; one (fig $3 \mathrm{C}$ ) showing a rapid fall to low concentrations of urinary free light chain but still remained positive in the urinary free light chain assay and on electrophoresis; urinary free light chain concentrations in the second case fell from 615 to $62 \mathrm{mg} / \mathrm{mmol}$ creatinine but rose thereafter. Two showed no biochemical response. These both had very low initial concentrations of urinary free light chains ( $3 \mathrm{mg} / \mathrm{mmol}$ creatinine); one showed very little change after chemotherapy and the 


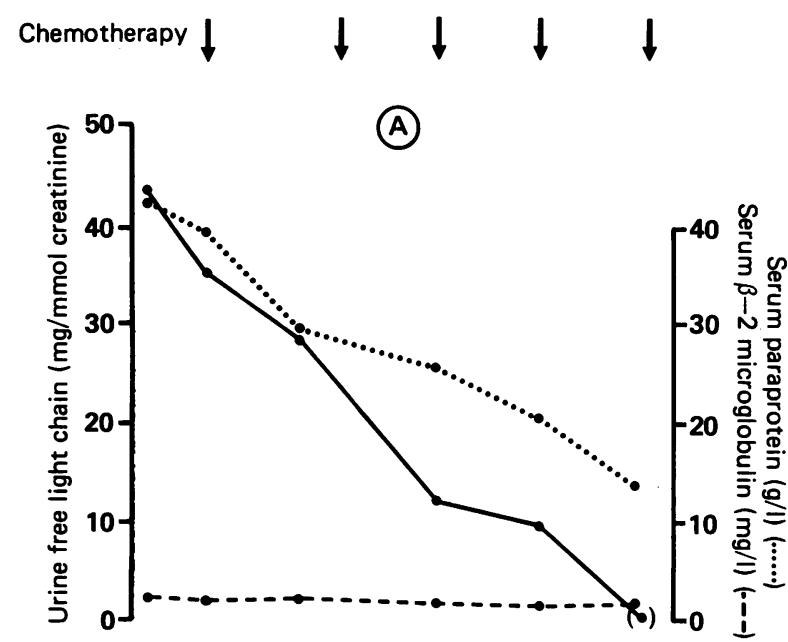

Chemotherapy $\downarrow \downarrow$
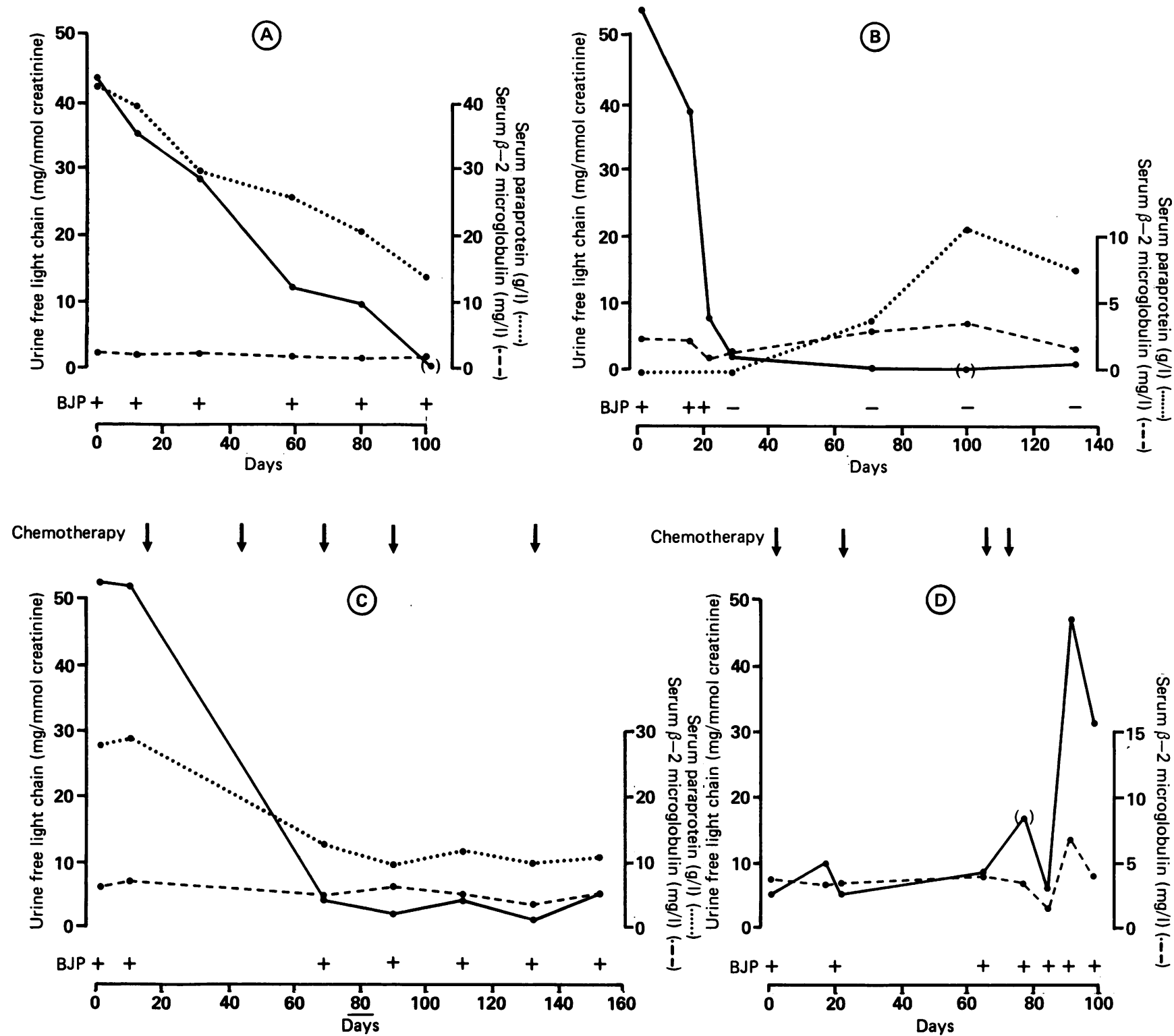

Figure 3 Comparison of the response of urine free light chain, serum paraprotein (if present), and serum $\beta-2$ microglobulin in four patients with myeloma receiving high dose chemotherapy. The qualitative result ( + positive, - negative) of a colloidal gold stain on the unconcentrated urine sample is shown at each assay point (BJP). Points on the urine free light chain assay graph, which were below the absolute sensitivity of the assay $(8 \mathrm{mg} / \mathrm{l})$, are shown in parentheses.

other (fig 3D) died shortly after a large rise in urinary free light chains and $\beta-2$ microglobulin. Correction of serum $\beta-2$ microglobulin valves for creatinine did not significantly affect the trend in each figure.

The urinary free light chain assay results correlated well with detection of Bence-Jones protein by cellulose acetate electrophoresis. Out of 75 samples, $64(85 \%)$ were positive and three $(4 \%)$ were negative on both assays. Five samples $(7 \%)$ were positive on electrophoresis and negative on free light chain assay. The limit of detection for gold stained cellulose acetate electrophoresis of unconcentrated urines has been estimated to be $2 \mathrm{mg} / 1,^{16}$ and this is corroborated by this study. It is noteworthy that two of these samples came from the two patients with paraprotein leaks in the urine. Although the presence of separate Bence-Jones bands was confirmed by immunofixation, paraprotein leaks might have been the cause of false positive results on electrophoresis. Three samples $(4 \%)$, all in one patient, were "negative" on electrophoresis but positive in the free light chain assay. There are several possible reasons for this and for false positive results generally in the free light chain assay. The free light chain assay does not distinguish between monoclonal and polyclonal light chain, so although a particular monoclonal Bence-Jones protein may have disappeared from the urine on electrophoresis, the free light chain assay will still detect polyclonal free light chain which may be present in increased amounts, particularly if the patient has a tubular proteinuria or renal failure. ${ }^{17}$ In this patient there was not only a mild tubular proteinuria, but several transient paraprotein 
bands had appeared in the urine and serum after chemotherapy. These could have been light chain fragments or transient Bence-Jones protein secreting clones, again as part of an oligoclonal response after chemotherapy. The original Bence-Jones protein band had gone and so they were reported as negative on electrophoresis, but the free light chain assay had presumably measured them. It would also be possible for a urinary "leak" of serum paraprotein to be of sufficient size to cause a cross reaction of urinary bound light chain in the free light chain assay and hence a false positive result. This was not apparently the case in the two patients with serum paraprotein leaks here, because the urinary immunoglobulins were too low.

Comparison with other markers: urinary free light chain concentrations with serum paraproteins in the nine cases which also had a serum monoclonal immunoglobulin $(\rho=0.542 ; t=4.2$ for $42 d f ; p<0.001)$ and it was our impression that significant falls in the serum paraprotein were generally accompanied by falls of a similar magnitude in urinary free light chain. In contrast, serum $\beta-2$ microglobulin did not correlate with urine free light chain concentrations $(\rho=-0 \cdot 15$; $t=-1.04$ for $46 d f ; \mathrm{p}>0.05)$ or with the serum paraprotein concentration $(\rho=0.057$; $t=0.43$ for $56 d f ; \mathrm{p}>0.05)$. Correcting the $\beta-2$ microglobulin for the serum creatinine using the regression formula of Cuzick et $a l^{18}$ and comparing the difference between the observed $\beta-2$ microglobulin and that predicted from the serum creatinine again showed no correlation with either urine concentrations $(\rho=0.13 ; t=0.95$ for $53 d f ; \mathrm{p}>0.05)$ or serum paraprotein $(\rho=-0 \cdot 19 ; t=-1 \cdot 28$ for $42 d f ; \mathrm{p}>0.05$ ). This would suggest that $\beta-2$ microglobulin may not be a suitable marker for monitoring Bence-Jones myeloma, as has been recommended $^{19}$; the serum $\beta-2$ microglobulin concentration in the patients studied here did not change as rapidly or by as much after treatment as the other markers.

\section{Conclusions}

The immunoturbidimetric assay for free light chains described here is much simpler and more rapid than any previously described free light chain radioenzyme immunoassay. It does not require very prolonged incubation times and multiple washing steps, and a result can be made available within 30 minutes of receiving a sample. Although it requires more antiserum than that used in the more sensitive assays, where high antiserum dilutions and prolonged incubations are used to achieve high sensitivity, the raw material cost is offset by the large reduction in time required to perform the assay. Furthermore, the shelf-life of the immunoturbidimetric assay is determined only by the antiserum, which is considerably longer than that of $I^{125}$ and at least equivalent to an enzyme immunoassay.

The sensitivity of the immunoturbidimetric $(5 \mathrm{mg} / \mathrm{l})$ is not as great as some of the enzyme immunoassays $(0.5$ to $60 \mu \mathrm{g} / \mathrm{l})$, but the utility of such sensitive assays for Bence-Jones protein assays is highly questionable when the upper limit of normal for free light chains in urines is of the order of $2-8 \mathrm{mg} / \mathrm{l}$. The only method for determining the presence of Bence-Jones protein below this level of polyclonal background is electrophoresis, which is always required to establish the clonal state of any abnormal immunoglobulin or free light chain measurement.

It could be argued that there is little role at present for Bence-Jones protein quantitation in myeloma. Urinary Bence-Jones protein, particularly $\lambda$ Bence-Jones protein, is not as good a marker of tumour burden as serum paraprotein, probably because of the considerable metabolism of light chains by the kidney and their adverse effect on renal function. ${ }^{20}$ Serum free light chains measurements may need to be considered in renal failure and for those Bence-Jones proteins which polymerise and are not filtered at the glomerulus. For Bence-Jones myeloma, however, other quantitative assays for monitoring response to treatment are quite unsatisfactory: urine total protein assays are notoriously inaccurate and imprecise and they only truly reflect Bence-Jones protein concentrations in the urine when Bence-Jones protein is the major protein present. Patients with myeloma commonly have considerable degrees of proteinuria which will seriously decrease the sensitivity of the total protein assay. Serum $\beta-2$ microglobulin has an undoubtedly important role for assessment of prognosis in myeloma, ${ }^{18}$ but its role in monitoring disease is less clear. It has been reported as showing a good correlation with disease stage, total myeloma cell mass, chemotherapy response and disease activity, ${ }^{21-3}$ but good ${ }^{21} 22$ or poor ${ }^{24-26}$ correlation with paraprotein concentrations. Its main problem as a tumour marker is that the serum concentrations are affected by the glomerular filtration rate, requiring creatinine correction to remove the effect of diminished renal function, and urine concentrations are unreliable due to the effect of urine acid. It can show a rise after chemotherapy as in one of the patients studied here, and as a preterminal event. ${ }^{18}$ It has been suggested that $\beta-2$ microglobulin should be regarded as reflecting plasma cell proliferative activity and mass whereas the paraprotein reflects myeloma cell mass alone. ${ }^{26}$ The results presented here suggest that the magnitude of the response to treatment does not seem to be as great as that of the paraprotein or free light chains and that it is less specific and sensitive than either of these assays for serial monitoring of tumour cell mass.

The adoption of an immunoturbidimetric free light chain assay for long term monitoring of patients will require not only a supply of antiserum raised against a sufficiently large light chain pool, but also a systematic approach to the preparation of suitable multiclonal or polyclonal standards and cross calibration of such standards. These problems are not insurmountable and not much more difficult than those encountered in the immunochemical assay of serum immunoglobulins and 
paraproteins. The simplicity and convenience of this assay may lead to greater use of urine and serum free light chain measurements in BenceJones myeloma as a parameter on which to base possible response, outcome, and adoption of alternative therapeutic options.

We are most grateful to Mary Meldrum, clinical data manager, for collating the therapeutic information on the patients. Mary Meldrum and TJMcE are supported by the Cancer Research Campaign and Medical Research Council.

1 Love EM. The chemotherapy of Multiple myeloma. In Delamore IW, ed. Multiple myeloma and other paraproteinaemias. Edinburgh: Churchill Livingstone,
1986:353-74.

2 Hobbs JR. Bence-Jones proteins. In: Marks V, Hales CN, eds. Essays in medical biochemistry. London: The Biochemical Society and The Association of Clinical Biochemists, 1975:105-31.

3 Zelkowitz L, Yakulis V. Immunologic methods for the detection and quantification of Bence Jones proteins. $J$ Lab detection and quantification
Clin Med 1970;76:973-9.

4 Solling $K$. Free light chains in normal serum and urine determined by radioimmunoassay. Scand J Clin Lab

5 Cole PW, Durie BGM, Salmon SE. Immunoquantitation of free light chain immunoglobulins: application in multiple myeloma. J Immunol Methods 1978;19:341-9.

6 Tan M, Epstein WV. A direct immunologic assay of human sera for Bence-Jones proteins (L-chains). J Lab Clin Med 1965;66:344-56.

7 Smith AM, Thompson RA. Paraprotein estimation: a comparison of immunochemical and densitometric technique. J Clin Pathol 1978;31:1156-60.

8 Robinson EL, Gowland E, Ward ID, Scarffe JH. Radioimmunoassay of free light chains of immunoglobulins in immunoassay of free light chains
urine. Clin Chem 1982;28:2254-8.

9 Brouwer J, Otting-van der Ruit MO, Busking-van der Lely HB. Estimation of free light chains of immunoglobulins by enzyme immunoassay. Clin Chim Acta 1985;150:267-74.

10 Axiak SM, Krishnamoorthy L, Guinan J, Raison RL. Quantitation of free $\kappa$ light chains in serum and urine using a monoclonal antibody based inhibition enzymelinked immunoassay. J Immunol Methods 1987;99:141-7.

11 Lolli F, Amaducci L. Measurement of free kappa immuno- globulin light chains in the cerebrospinal fluid by a competitive avidin-biotin ELISA. Clin Chim Acto 1989;182:229-34

$12 \mathrm{Kohn} \mathrm{J}$. Cellulose acetate electrophoresis and immunoelectrophoresis. In: Smith I, ed. Chromatographic and electrophoretic techniques. Vol 2. London: Heineman 1976:90-137.

13 Righetti PG, Casero P, Del Campo GB. Gold staining in cellulose acetate membranes. Clin Chim Acto 1986;157:167-74.

14 Kohn J, Riches P. A cellulose acetate immunofixation technique. J Immunol Methods 1978;20:325-31.

15 Tillyer CR, Rawal Y. An immunoturbidimetric method for the measurement of beta-2 microglobulin in serum and plasma on a centrifugal analyser. Ann Clin Biochem plasma on a cent

16 Martin SM, Kohn J. The sensitivity of gold staining in the detection of Bence-Jones proteinuria. Ann Clin Biochem 1987;74:S120-2.

17 Hall CL, Hardwicke J. Low molecular weight proteinuria. Ann Rev Med 1979;30:199-211.

18 Cuzik J, Cooper EH, MacLennan ICM. The prognostic value of serum $\beta 2$ microglobulin compared with other presentation features in myelomatosis. $\mathrm{Br} J$ Cancer 1985;52:1-6.

19 Whicher JT, Calvin J, Riches P, Warren C. The laboratory investigation of paraproteinaemia. Ann Clin Biochem 1987;24:119-32.

20 Durie BGM, Cole PW, Chen HS, Himmelstein KJ, Salmon SE. Synthesis and metabolism of Bence Jones protein and calibration of tumour burden in patients with Bence Jones calibration of tumour burden in patients
myeloma. Br J Haematol 1981;47:7-19.

21 Bataille R, Grenier J, Sany J. Beta 2 microglobulin in myeloma: optimal use for staging, prognosis and treatment. Blood 1984;63:468-75.

22 Garewal H, Durie BGM, Kyle RA, Finley P, Bower B Serokman R. Serum beta 2 microglobulin in the initial staging and subsequent monitoring of monoclonal plasma cell disorders. J Clin Oncol 1984;2:51-7.

23 Bataille R, Grenier J. Serum Beta 2 microglobulin in multiple myeloma. A critical review. Eur $J$ Cancer Clin Oncol 1987;23:1829-32.

24 Norfolk D, Child JA, Cooper EH, Kerruish S, Ward A Serum beta 2 microglobulin in myelomatosis: potential value in stratification and monitoring. $\mathrm{Br} J$ Cancer value in stratificat

25 Scarffe JH, Anderson H, Palmer MK, Crowther D. Prognostic significance of pretreatment levels of beta-2microglobulin levels in multiple myeloma. Eur J Clin Oncol 1983;19:1361-4.

26 Di Giovanni S, Valenti G, Ravazzolo E, Carducci P, Giallonardo $\mathrm{P}$, Maschio C. Serum $\beta 2$-microglobulin in patients with monoclonal gammopathies. Int $J$ Biol Markers 1987;2:169-72. 